
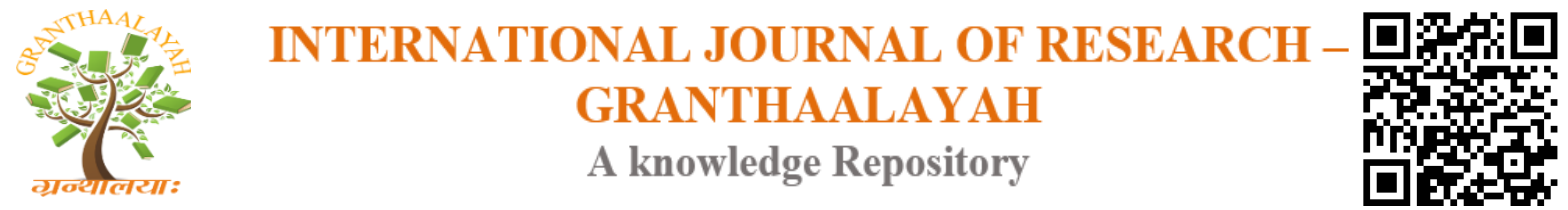

Management

\title{
FOREIGN INVESTMENT INFLOWS AND THE STRUGGLE FOR A RENEWED ECONOMIC GROWTH IN NIGERIA: AN ECONOMETRIC STUDY
}

\author{
Aderopo Raphael Adediyan *1, Emmanuel Ekomoezor ${ }^{2}$ \\ ${ }^{* 1,2}$ Economics Department, University of Benin, Benin City, Nigeria
}

\begin{abstract}
This study attempts to find answer to the question of whether Nigeria should intensify effort to draw home more foreign investment; would more of foreign investment inflows accelerate Nigeria economic performance? Methodologically, annual time series data from 1986 to 2018 was analyzed using ARDL approach. The key findings are that, although FDI has long-run positive impact on economic growth, FPI has no operational effect on the growth; this is true of FPI both in the long-run and short-run. Furthermore, labour force and trade openness were found to have long-run and short-run positive impact on growth. Hence, government must tactically open up economy to trans-border trade, increase labour supply and intensify effort to attract more FDI.
\end{abstract}

Keywords: ARDL; Co-integration; Economic Growth; FDI; FPI.

Cite This Article: Aderopo Raphael Adediyan, and Emmanuel Ekomoezor. (2019). "FOREIGN INVESTMENT INFLOWS AND THE STRUGGLE FOR A RENEWED ECONOMIC GROWTH IN NIGERIA: AN ECONOMETRIC STUDY." International Journal of Research - Granthaalayah, 7(8), 88-103. https://doi.org/10.29121/granthaalayah.v7.i8.2019.642.

\section{Introduction}

One of the economic benefits of an open economy is the free movement of capital or assets in the form of foreign investment. Several economies like Ghana, Nigeria and South Africa are now documenting fast-paced growing inflows of foreign investment into the economy. Foreign investment is believed to complement domestic investment; hence, a perceived prerequisite to the achievement of a sustained rate of economic growth. Economic literature suggested foreign portfolio investment and foreign direct investment as the two basic forms in which the foreign investment may be classified.

Foreign portfolio is an aspect of foreign capital flows, consisting of financial assets like stocks and bonds in the financial markets. One key feature of foreign portfolio investment that is often an issue of concern is its level of volatility which cannot guarantee or maintained a sustainable economic growth (Ahmad et al., 2004; Obadan, 2004). 
In this spirit, Ahmad et al. (2004) contended that the high risk or volatility level observed in holding foreign portfolio compared to foreign direct investment makes the latter more preferable to the former by the recipient economies, as such many economies depend more on FDI to achieve the targeted economic growth rate by simply adjusting their business environments to be more opened and suitable for foreign direct investment (Baghebo and Apere, 2014). On the other hand, foreign portfolio investment vis-à-vis the capital market could benefits economy by stimulating liquidity of the capital market, and promoting long term fund raising essential for a rapid economic growth rate.

Foreign direct investment, in contrast, is the transferring of investment resources such as technology and capital from the source economy to the recipient economy. Such economic resources are often beneficial to the hosting economy in terms of enlarging the production capabilities, raising the social welfare and the increment in income. Although, a key argument in favour of FDI may be that it increases the real domestic income of the host economy more than the profits repatriated to the source economy and could also help to achieve a broad tax-base and a well-diversified economy, FDI is not totally a zero-sum game investment strategy; it has detrimental aspects for the recipient economy. An instance of this is the possibility of a rising rate of wage differential or inequality in the recipient economy (Moosa, 2002).

Despite the fact that foreign direct investment carries possibility of a stable economic growth than the foreign portfolio, both are seen as more plausible foreign investment choice (Rasin, 2002). In view of this, policymakers often seek for an array of strategies to attract foreign investment into the economy. Central to the attraction of foreign investment into the hosting economy is the nature of the business environment or the degree of ease of doing business in such an economy (Baghebo and Apere, 2014).

The business environment in Nigeria in the past, particularly during the pre-SAP period, was characterized by excessive government intervention and the intensive imposition of the policy of trade restriction (Onyeisi et al., 2016) without any serious incentives to draw home the foreign investors. Accordingly, the Nigerian Enterprises Promotion Decree, Exchange Control Act, nationalization and indigenization policies etc embarked during the pre-SAP period, to a good extent, impeded the foreign investment inflows. In this way, the Nigerian investment climate had little appeal to the foreign investors in the pre-SAP period.

In spite of the fact that those policies may be said to guarantee trade fairness, protection of indigenous/local capital from foreign firms, obliging Nigeria to be a partner to foreign firms, and in general, increasing local content, it failed to achieve the desirable rate of economic growth: economic performance was not at its best, evidenced by the poor performance of the key macroeconomic indicators. For instance, the Nigerian GDP growth rate dropped successively from $8.6 \%$ in 1963 to $5 \%, 4.9 \%,-4.3 \%$ and -15 in 1964, 1965, 1966 and 1967 (WDI, 2018).

However, during the period of the adoption of SAP policy, Nigeria attracted foreign investment into the economy by formulating and implementing business-friendly policies as well as offering of several investment motivation packages with a view to achieving a stable and virile economy. Subsequently, the Company and Allied Matter Act of 1989 (took effect in 1990) was promulgated 
to further make investment atmosphere conducive for new and already established investors in the country.

Furthermore, in 1991, the banks and other financial institutions decree number 25 was enacted to monitor banking and non-banking financial operation with the aim of making Nigerian economy an attractive destination of investments. Furthermore in the mid-90s, the Nigerian government undertook several policy reviews: both the Exchange Control Act of 1962 and the Nigerian Enterprises Promotion Decree of 1989 were repealed and the new decrees establishing the Nigerian Investment Promotion Commission (established through the Decree number 16 of 1995) and the Foreign Exchange - Monitoring and Miscellaneous Provisions Decree 17 of 1995 were promulgated (Onyeisi et al., 2016).

The repealing of the two decrees and their subsequent replacement with newer ones appears to induce more foreign investment inflow. As observed by Onosode (1998) in (Obadan, 2004, p.8) "between July 1995 and July 1996, about US\$6.0 million foreign portfolio investment was made in the Nigerian capital market through the Nigerian Stock Exchange for the first time since 1962". Surprisingly, in spite of the series of investment-enhanced strategies or policy packages employed to increase foreign investment inflows, and the resulting rate of growth of foreign investment achieved, as showed by Balance of Payment (BOP), the Nigerian economy is yet to perform appreciatively. For example, the actual GDP growth rate of $6.73,7.20,4.21,6.22,-1.58$ and 0.82 in 2006, 2008, 2012, 2014, 2016 and 2017 seriously lagged behind the targeted rate of growth of $7,10,7.30,7.02,3.59$, and 4.09 respectively. Hence, one wonders if foreign investment inflow a significant determinant of Nigerian economic growth. Also, should the Nigerian government focus more on attracting foreign investment to improve economic growth? Therefore, the main objective of this paper is to address the two fundamental issues.

The rest of this paper is portioned as follow: section 1.1 presents trend in foreign investment inflows and economic growth (GDP) in Nigeria. Brief reviews of the literature in section 2; the theoretical framework and methodology are in section 3; section 4 details empirical results and implication of findings. The conclusion and recommendations are in section 5 .

\subsection{Trend in Foreign Investment Inflows and Economic Growth in Nigeria}

In order to provide a clear understanding of the relevance of foreign investment inflows into the economy, we proceed to discuss the trend and some sectoral destinations of foreign investment inflows into Nigeria. The two basic components of foreign investment inflow need to be mentioned here; the foreign direct investment and foreign portfolio investment, both of which shall hereafter be referred to as FDI and FPI respectively. As observed in the Table 1, the inflows of FDI have been tremendous in the past years, contributing greatly to GDP in 2008, 2009 and 2011.I

Table 1: FDI Inflows and GDP Growth from 2005 to 2017 (N' Billion)

\begin{tabular}{|l|c|c|c|c|c|}
\hline FDI & $\begin{array}{c}\text { Equity } \\
\text { Capital (1) }\end{array}$ & $\begin{array}{c}\text { Reinvested } \\
\text { earnings and } \\
\text { others (2) }\end{array}$ & $\begin{array}{c}\text { Total } \\
\text { (3) }\end{array}$ & $\begin{array}{c}\text { \% Share of (3) } \\
\text { in GDP }\end{array}$ & GDP \\
\hline 2005 & 423.3 & 230.9 & 654.2 & 1.745699 & 37474.95 \\
\hline 2006 & 388.6 & 240.6 & 629.2 & 1.573177 & 39995.5 \\
\hline
\end{tabular}


DOI: 10.5281/zenodo.3380018

\begin{tabular}{|l|c|c|c|c|c|}
\hline 2007 & 491.1 & 268.2 & 759.3 & 1.769006 & 42922.41 \\
\hline 2008 & 584.0 & 387.5 & 971.5 & 2.111382 & 46012.52 \\
\hline 2009 & 802.6 & 471.2 & 1273.8 & 2.554953 & 49856.1 \\
\hline 2010 & 475.1 & 430.6 & 905.7 & 1.658419 & 54612.26 \\
\hline 2011 & 877.1 & 483.2 & 1360.3 & 2.365285 & 57511.04 \\
\hline 2012 & 636.1 & 477.4 & 1113.5 & 1.858004 & 59929.89 \\
\hline 2013 & 451.0 & 424.1 & 875.1 & 1.384242 & 63218.72 \\
\hline 2014 & 317.9 & 420.2 & 738.1 & 1.099135 & 67152.79 \\
\hline 2015 & 181.1 & 420.9 & 602 & 0.872161 & 69023.93 \\
\hline 2016 & 714.2 & 410 & 1124.2 & 1.654909 & 67931.24 \\
\hline 2017 & 553.5 & 516.0 & 1069.5 & 1.561519 & 68490.98 \\
\hline
\end{tabular}

Source: Compiled from CBN 2017 Annual Statistical Bulletin

In Table 1, about $\$ 654.2$ billion worth of FDI inflows were recorded in 2005, consisting roughly 1.75 per cent of GDP, of which, 423.3 billion was the equity capital and 230.9 billion came from reinvested earnings and others. In 2009, FDI rose significantly to about 1273.8 billion and accounted for about 2.55 percent of GDP. This increase was driven by the growth in equity capital. As at the end of 2016 and 2017, the inflows of FDI into the Nigerian economy are much higher compared to the amount recorded in 2005 and 2015 with equity capital appearing as the dominant contributor to the growth of FDI in those periods.

The FDI growth rate reduced from about $\$ 1360.31$ billion in 2011 to roughly $\$ 602.1$ billion in 2015; thus, its share contribution to GDP fell from 2.37 per cent to 0.87 per cent. In terms of sectoral destination of FDI in Nigeria, Tumala, Ajibola, Omotosho and Baruwa (2013) argued that the extractive sector, followed by manufacturing, and transport, storage and communication were the sectors with the highest record of FDI especially between 2010 and 2011 while agriculture, hunting, forestry and fishing sector ranked low.

In the case of FPI, the growth trend in Table. 2 shows that although Nigeria experienced a steady growth in FPI in the past, especially between 2005 and 2007, the highest level of growth in FPI was in 2012 and 2017 during which FPI inflows accounted for over 4 per cent and 3 per cent of GDP growth. Table 2 further suggests that FPI growth was about 116.6 billion in 2005 with the highest contribution coming from equity securities (about 98.6billion) while the remaining N17.5billion came from debt securities and others.

Table 2: FPI Inflows and GDP Growth Rate from 2005 to 2017 (N' Billion)

\begin{tabular}{|l|c|c|c|c|c|}
\hline Fear & $\begin{array}{c}\text { Equity } \\
\text { Securities (1) }\end{array}$ & $\begin{array}{c}\text { Debt Securities } \\
\text { and others (2) }\end{array}$ & $\begin{array}{c}\text { Total } \\
\mathbf{( 3 )}\end{array}$ & $\begin{array}{c}\text { \% share of (3) } \\
\text { in GDP }\end{array}$ & GDP \\
\hline 2005 & 98.6 & 17.4 & 116.0 & 0.30954 & 37474.95 \\
\hline 2006 & 227.6 & 132.07 & 359.67 & 0.899276 & 39995.5 \\
\hline 2007 & 182.1 & 150.5 & 332.6 & 0.774887 & 42922.41 \\
\hline 2008 & $(113.0)$ & 270.2 & 157.2 & 0.341646 & 46012.52 \\
\hline 2009 & 72.6 & $(1.7)$ & 70.9 & 0.142209 & 49856.1 \\
\hline 2010 & 323.6 & 232.9 & 556.5 & 1.019002 & 54612.26 \\
\hline 2011 & 395.6 & 396.8 & 792.4 & 1.377822 & 57511.04 \\
\hline 2012 & 1568.5 & 1118.7 & 2687.2 & 4.483906 & 59929.89 \\
\hline 2013 & 870.3 & 1259.9 & 2130.2 & 3.369572 & 63218.72 \\
\hline
\end{tabular}




\begin{tabular}{|l|c|c|c|c|c|}
\hline 2014 & 164.3 & 668.1 & 832.4 & 1.239561 & 67152.79 \\
\hline 2015 & $(93.6)$ & 591.8 & 498.2 & 0.721779 & 69023.93 \\
\hline 2016 & 82.2 & 394.8 & 477.0 & 0.702181 & 67931.24 \\
\hline 2017 & 892.7 & 1711.6 & 2604.3 & 3.802399 & 68490.98 \\
\hline
\end{tabular}

Source: Compiled from CBN 2017 Annual Statistical Bulletin

From Table 2, it is evidence that fluctuation or shock in the growth level of FPI mostly comes from debt securities except in 2005, 2006 and 2007 when equity securities took the lead.

\section{Literature Review}

\subsection{Review of Theoretical Literature}

The need to achieve an accelerated rate of economic growth by many nations has led several Macroeconomics scholars to investigate for the drivers of economic growth. We will discuss some of the identified drivers of economic growth by studying the varieties of the macroeconomic model built and the theories postulated. It is critical to note, at this juncture, that a number of these theories have contrary or common position, that the stock of investible resources, such as capital, labour, and technology, available either locally or imported into the host economy, and its subsequent utilization in such economy is often responsible for the nature of growth of that economy.

Among the first generation of these macroeconomics theories propounded on growth is Ricardo's classical theory of international trade (comparative advantage) which highlighted the gains that could be benefited owing to a free inter-boundary movement of goods (Ricardo, 1851). However, the theory fails to explain to our understanding FDI as a source of economic growth. Going down memory lane of the classic economic literature of the 1950s and 1960s, economic theorists viewed economic growth as a process - successive stages in which the less-developed economies must pass through to be developed. This is the view of the popular linear stages of the growth model.

Todaro and Smith (2012) argued that the linear stages of the growth model is principally an economic theory meant to explain the right combination of investment, saving, and foreign aid as a necessity for the less-developed economies to move along an economic growth pathway known to had been historically followed by the developed economies. Although the 1970s linear growth approach in no small way replaced the earlier version with much focus on the patterns of structural transformation and institutional constraint on the economic development or growth, it has been disapproved of on the ground that it does not explain the source of economic growth as such.

The Harrod-Domar model on the other hand explicitly accounts for the source of economic growth. The model argued that in order to achieve growth, a new investment which implies net additions to the capital stock is a necessity. New investment can be made if a certain proportion of GDP is saved and invested. According to the model, the new investment project would bring a corresponding increase in the output (GDP) growth. Hence the model is based on the assumption of a fixed proportion production function. The model presumes a direct relationship between the GDP and the total size of the capital stock (Jhingan, 2013). 
The Harrod-Domar model accords a prominent role to investment (be it foreign or local) in the process of economic expansion in two ways: it generates income and supplements the economy's productive capacity by raising its capital stock. Therefore, provided investment is undertaking, output and real income will continue to rise. It is in this spirit that Bhagwati, (1994) opined that increasing the resources dedicated to investment is the hub of a problem of development. HarrodDomar model is flawed by assuming a fixed proportion production and with no explicit treatment of labour force growth (Todaro and Smith, 2012).

Solow growth model overcame the basic shortcoming of the Harrod-Domar model by postulating a continuous Production function that permits endless substitutability of factors (labour and capital). In Solow's growth model, three main variables were focused on as the basic driver of economic growth: capital (investment), technological advancement, and the effectiveness of labor (knowledge). In the model, Solow stressed that output per labour depends only on capital per labour; output per labour produced rises as the size of the capital per labour used increases over time (Romer, 2012 and Snowdon and Vane, 2005).

The Solow model which took its root from the neoclassical production function framework with decreasing returns to capital draws attention to the growth in population, an increment of saving (investment), and technological progress. The model presumes the saving rate (investment) and the growth of the population to be exogenous. The model presents these two (2) variables as the determinants of the steady-state level of income per capita. The model argued that the more the saving (investment) rate, the richer the country, and the higher the growth rate of the population, the poorer the country (Mankiw et al., 1992).

Solow neoclassical model sees the impact of growth in the rate of savings (investment) on the output per worker to be positive and temporary. But after some adjustment in the long-run, growth in investment has no effect on economic growth, although it will increase the level of output per worker (Blanchard and Johnson, 2013; Snowdon and Vane, 2005). In conclusion, the Solow growth model implies that in the absence of technological progress the ability of a given economy to increase output per worker by means of accumulation of capital is constrained by the interplay of the people's willingness to save, diminishing returns, the rate at which capital stock depreciates, and the growth rate of the population.

Romer (2012) contends that Solow's growth model is inadequate. According to him, growth is not constant for both "growth miracle countries" such as Singapore and South Korea and "growth disaster countries" e.g. Argentina. In addition, Mankiw et al (1992) argued that the impact of population growth and the physical capital will be higher on income or growth if the effect of the human capital accumulation is considered. Therefore, by incorporating human capital into the Solow's growth model, Mankiw et al (1992) came up with another economic model, Augmented Solow model, that acknowledged the human capital as a source and a driver of economic growth. As may be observed, virtually all of the above models do not explicitly take into consideration the impact of foreign investment in the determination of economic growth; rather, it is presumed that foreign investment is a component of the total capital stock available in the economy and therefore affects economic growth. But, the total capital stock available in the economy at any point in time embodies local private investment stock and government capital stock etc; hence, the nature of the effect of foreign investment may not be well defined in the above models. 
However, a model that seems to explicitly identify foreign investment as a source of economic growth is the gap model. According to Todaro (1994), foreign investment increasingly fills the gaps between locally available investment or savings and the intended level of economic resources necessary to realize the desired developmental targets. Additionally, Bhagwati (1994), Brecher and Findlay (1983), Brecher and Diaz-Alejandro (1977) came up to explain foreign investment as a source of growth through what they called Bhagwati hypothesis.

The authors postulated that foreign investment inflow into a restrictive import-substitution strategy economy retards economic growth. A reason may be that in a strict import-substitution economy, foreign investment typically takes place in the sectors where the hosting economy lacks comparative advantage. Therefore, foreign investment turns to a way of maintaining the market share by the foreign companies as well as to enjoy the additional profit they generated.

\subsection{Empirical Review of Literature}

Some earlier studies have attempted to investigate foreign investment as a determinant of economic growth. Kania-Morales and Mróz (2014) empirical study asked perhaps foreign portfolio investment and foreign direct investment really determine economic growth in Germany, Poland, and in Great Britain. The study employs Johannsen Co-integration and VEC. In case of Poland, the study finds that a significant long-run relationship between economic growth and stocks of foreign investment (FDI and FPI) exist, but this relationship was not found for the United Kingdom and Germany.

Okafor et al (2016) adopting the Toda-Yamamoto method of causality test investigated the link between Nigerian economic growth and foreign capital inflows. The result obtained suggests a bidirectional relationship between economic growth and foreign direct investment. On the other hand, a unidirectional relationship is found between foreign portfolio investment and economic growth with the causation running from foreign portfolio to economic growth.

Odubola and Desalu (2017) studied domestic investment and foreign direct investment as the determinants of economic growth between 1985 and 2015 in Nigeria. The study employs the Ordinary Least Square (OLS) technique. The study suggested that foreign direct investment is not a contributing factor to economic growth in Nigeria. Because of the problem associated with the econometric instrument used, the findings of the authors may not be reliable.

The study of Ibrahim and Akinbobola (2017) takes the above shortcoming into consideration by adopting the VAR model in the course of investigating whether the foreign portfolio investment determines economic growth in Nigerian's democratic settings. The outcome of their research showed a significant positive link between economic growth and foreign portfolio investment in the long-run in Nigeria.

Tang (2015) examines whether economic growth in the European Union Countries had been boosted by foreign direct investment. The study employs 2SLS, FGLS, and GMM. The finding of the study showed that foreign direct investment is capable of promoting economic growth. Lastly, Albulescu (2005) investigated the long-run impact of foreign direct and portfolio investments on economic growth in the Central and Eastern part of Europe from 2005 to 2012. The study adopted 
the system-GMM estimation technique. The study finds foreign portfolio and foreign direct investment to exert positive and statistically significant influence on economic growth in the region.

Although there are several empirical studies on the impact of foreign direct investment and foreign portfolio on growth, only few of these studies combine the two and weigh their impacts on economic growth simultaneously in Nigeria. Also, most of the studies presume neutral effect of labour force on growth with more on the effect of foreign investment particularly the FDI on growth; however, availability of labour force may reinforce the impact size of foreign investment on economic growth. This study therefore, employing ADRL model and more current data attempts to fill the aforementioned gaps.

\section{Model Specification, Data and Estimation Method}

\subsection{Model Specification}

To determine whether accelerating economic growth vis-à-vis growth in foreign investment inflows is pragmatic, the study follows Cobb-Douglas (C-D) production function, mathematically represented as:

$Y=f\left(K^{\alpha}, L^{\beta}\right)$

The C-D production function in equation 1 presupposes capital and labour to be the basic determinants of output (Y). Suppose Y is the Nigerian real GDP, and let foreign investment inflows to assume the role of productive capital input in the Nigerian economy's production function, since foreign investment inflow is a private capital resource; therefore, we augment equation 1, adding trade openness, and specify the model as:

$R G D P(t)=\mathrm{f}\left(F I^{\alpha}(\mathrm{t}), \operatorname{LBF}^{\beta}(\mathrm{t}), \operatorname{TROP}^{\lambda}(\mathrm{t})\right)$

But

$F I^{\alpha}(t)=f\left(F D I^{\omega}(t), F P I^{\Upsilon}(t)\right)$

Thus, substituting equation 3 into 2 yields

$R G D P(t)=f\left(F D I^{\omega}(t), F P I^{\gamma}(t), L B F^{\beta}(\mathrm{t}), T R O \mathrm{P}^{\lambda}(\mathrm{t})\right)$

Applying logarithm transformation, an econometric representation of equation 4 is:

$R G D P_{(t)}=\phi_{0}+\omega \operatorname{LnFDI}(t)+\gamma \operatorname{LnFPI}(t)+\beta \operatorname{LnLBF}(t)+\lambda \operatorname{LnTROP}(t)+\varepsilon(t)$

Our a'priori expectation is that: $\omega>0, \gamma>0, \beta>0$ and $\lambda>0$.

Where RGDP is the real GDP, FDI stands for foreign direct investment (net FDI as a fraction of GDP), FPI is the foreign portfolio investment (net FPI as a percentage of GDP); LBF symbolizes 
labour force, TROP is the trade openness and ( $\mathrm{t}$ ) represents time. The $\gamma, \omega, \beta$ and $\lambda$ represent the level of sensitivity of its associated variable to economic growth.

\subsection{Data Sources}

The data used in this study were sourced from the World Bank database and CBN annual statistical bulletin of various issues. The data sourced from the World Bank database are on foreign direct investment, foreign portfolio investment, real GDP and the labour force while data on trade openness was sourced from the CBN annual statistical bulletin. The data sourced for the study spanned from 1986 to 2018.

\subsection{Estimation Method}

The estimation method adopted follows the Autoregressive Distributed Lag (ARDL) Bound testing approach suggested by Pesaran et al. (2001). This method is applicable irrespective of whether the variables used are of I(0), I(I) or both (Narayan, 2004; Perasan et al, 2001).

In the absence of prior knowledge of the direction of the steady state or long-run relationship among the variables: LnRGDP, LnFDI, LnFPI, LnLBF and LnTROP, the under listed unrestricted error correction model regression equations, where each variable assumes own equation, are estimated.

$$
\begin{aligned}
& \Delta \operatorname{LnRGDP_{(t)}}=y_{0}+\sum_{\pi=1}^{k} \mathrm{a} \pi_{R G D P} \Delta \operatorname{LnRGDP}(t-\pi)+\sum_{\pi=0}^{k} b \pi_{R G D P} \Delta \operatorname{LnFDI} I_{(t-\pi)}+ \\
& \sum_{\pi=0}^{k} C \pi_{R G D P} \Delta L n F P I_{(t-\pi)}+\sum_{\pi=0}^{k} d \pi_{R G D P} \Delta L n L B F_{(t-\pi)}+\sum_{\pi=0}^{k} \text { e } \pi_{R G D P} \Delta \operatorname{LnTROP}(t-\pi)+
\end{aligned}
$$

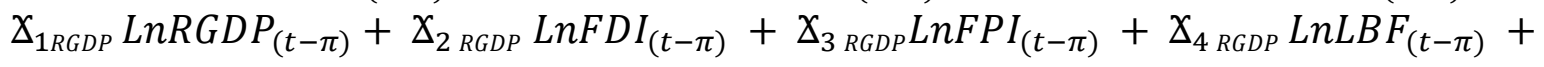

$$
\begin{aligned}
& \chi_{5 \text { RGDP }} \operatorname{LnTROP}(t-\pi)+\varepsilon_{2 t} \\
& \Delta L n F D I_{(t)}=y_{0}+\sum_{\pi=1}^{k} \mathrm{a} \pi_{F D I} \Delta L n F D I_{(t-\pi)}+\sum_{\pi=0}^{k} b \pi_{F D I} \Delta L n R G D P_{(t-\pi)}+\sum_{\pi=0}^{k} C \pi_{F D I} \Delta L n F P I_{(t-\pi)} \\
& +\sum_{\pi=0}^{k} d \pi_{F D I} \Delta \operatorname{LnLBF}_{(t-\pi)}+\sum_{\pi=0}^{k} e \pi_{F D I} \Delta \operatorname{LnTROP}(t-\pi)+X_{1 F D I} \operatorname{LnFDI}(t-\pi) \\
& +\chi_{2 F D I} \operatorname{LnRGDP}(t-\pi)+\chi_{3 F D I} \operatorname{LnFPI}_{(t-\pi)}+\chi_{4 F D I} \operatorname{LnLBF}_{(t-\pi)} \\
& +\chi_{5 F D I} \operatorname{LnTROP}(t-\pi)+\varepsilon_{2 t} \\
& \Delta L n F P I_{(t)}=y_{0}+\sum_{\pi=1}^{k} \mathrm{a} \pi_{F P I} \Delta L n F P I_{(t-\pi)}+\sum_{\pi=0}^{k} b \pi_{F P I} \Delta L n R G D P_{(t-\pi)}+\sum_{\pi=0}^{k} C \pi_{F P I} \Delta L n F D I_{(t-\pi)} \\
& +\sum_{\pi=0}^{k} d \pi_{F P I} \Delta \operatorname{LnLBF}_{(t-\pi)}+\sum_{\pi=0}^{k} e \pi_{F P I} \Delta \operatorname{LnTROP}(t-\pi)+\chi_{1 F D I} \operatorname{LnFPI}(t-\pi) \\
& +\chi_{2 F P I} \operatorname{LnRGDP}(t-\pi)+\chi_{3 F D I} \operatorname{LnFDI}(t-\pi)+\chi_{4 F D I} \operatorname{LnLBF}(t-\pi) \\
& +\chi_{5 F D I} \operatorname{LnTROP}(t-\pi)+\varepsilon_{3 t}
\end{aligned}
$$




$$
\begin{aligned}
& \Delta L n L B F_{(t)}=y_{0}+\sum_{\pi=1}^{k} \mathrm{a} \pi_{L B F} \Delta L n L B F_{(t-\pi)}+\sum_{\pi=0}^{k} b \pi_{L B F} \Delta L n R G D P_{(t-\pi)} \\
& +\sum_{\pi=0}^{k} C \pi_{L B F} \Delta L n F P I_{(t-\pi)}+\sum_{\pi=0}^{k} d \pi_{L B F} \Delta L n F D I_{(t-\pi)}+\sum_{\pi=0}^{k} e \pi_{L B F} \Delta \operatorname{LnTROP}(t-\pi) \\
& +\searrow_{1 L B F} \operatorname{LnLBF}(t-\pi)+\searrow_{2 L B F} \operatorname{LnRGDP_{(t-\pi )}}+\searrow_{3 L B F} \operatorname{LnFPI}(t-\pi) \\
& +\chi_{4 L B F} \operatorname{LnFDI}(t-\pi)+X_{5 L B F} \operatorname{LnTROP}(t-\pi) \\
& +\varepsilon_{3 t} \\
& \Delta \operatorname{LnTROP}(t)=y_{0}+\sum_{\pi=1}^{k} \mathrm{a} \pi_{T R O P} \Delta \operatorname{LnTROP}(t-\pi)+\sum_{\pi=0}^{k} b \pi_{T R O P} \Delta \operatorname{LnRGDP_{(t-\pi )}} \\
& +\sum_{\pi=0}^{k} C \pi_{T R O P} \Delta L n F P I_{(t-\pi)}+\sum_{\pi=0}^{k} d \pi_{T R O P} \Delta L n L B F_{(t-\pi)}+\sum_{\pi=0}^{k} e \pi_{T R O P} \Delta L n F D I_{(t-\pi)}
\end{aligned}
$$

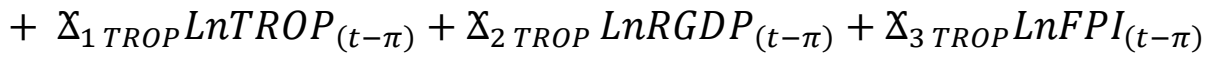

$$
\begin{aligned}
& +\chi_{4 R O P} \operatorname{LnLBF}(t-\pi)+\chi_{5 T R O P} \operatorname{LnFDI}(t-\pi)+\varepsilon_{3 t}
\end{aligned}
$$

Where $\Delta$ defines the first difference operator; the parameters $x_{1}, \ldots, \chi_{5}$ represent the multipliers of the long-run. Furthermore, the parameters a, .., e are the coefficients representing the shortrun.

In each of equation 6 to 10, the null hypothesis of no co-integration or no long-run relationship among the variables is generally specified as:

$\mathrm{H}_{0}: \quad \mathrm{X}_{1}=\mathrm{X}_{2}=\mathrm{X}_{3}=\mathrm{X}_{4}=\mathrm{X}_{5}=0 \quad$ alongside the alternative hypothesis that

$\mathrm{H}_{1}: \quad x_{1}=x_{2}=x_{3}=x_{4}=\chi_{5} \neq 0$

The computed F-statistic (Wald) for each of the equations is compared with the upper and lower bound critical values; for this purpose, we employed Narayan (2004) critical values.

Given the existence of a long-run relationship in the model, equation 5 is therefore estimated via the ARDL ( $\mathrm{f}, \mathrm{g}, \mathrm{h}, \mathrm{j}, \mathrm{k}$ ) model below:

$$
\begin{aligned}
& \operatorname{LnRGDP}(t)=y_{0}+\sum_{\pi=1}^{f} y_{1} \operatorname{LnRGDP}(t-\pi)+\sum_{\pi=0}^{g} y_{2} \operatorname{LnFDI}(t-\pi)+\sum_{\pi=0}^{i h} y_{3} \operatorname{LnFPI}(t-\pi) \\
& +\sum_{\pi=0}^{j h} y_{4} \operatorname{LnLBF}(t-\pi)+\sum_{\pi=0}^{k} y_{5} \operatorname{LnTROP}(t-\pi)+\mu
\end{aligned}
$$


The short-run of equation 11 is:

$$
\begin{aligned}
& \Delta \operatorname{LnRGDP}(t)=\phi_{0}+\sum_{\pi=1}^{f} \phi_{1} \Delta \operatorname{LnRGDP}(t-\pi) \\
& \sum_{\pi=0}^{i h} \phi_{3} \Delta \operatorname{LnFPI} I_{(t-\pi)}+\sum_{\pi=0}^{g h} \phi_{4} \Delta \operatorname{LnLBF}_{(t-\pi)}+\sum_{\pi=0}^{k} \phi_{2} \Delta \operatorname{LnFDI} \phi_{(t-\pi)}+\operatorname{LnTROP}_{(t-\pi)}+\gamma \mathrm{ECM}_{(\mathrm{t}-\pi)}+ \\
& \text { (12) }
\end{aligned}
$$

Where ECM stands for error correction model, and its associated coefficient, $\gamma$, is the speed of adjustment. Narayan (2004) contends that if the F-statistic lies in-between the lower and the upper bound, a conclusive inference would be difficult to make except the order of integration of the underlying regressors in the model is known. Consequently, unit root test will be conducted using Augmented Dickey-Fuller and Philip-Perion tests.

\section{Empirical Results}

In this section, the findings of the study are presented, starting from the basic descriptive statistics of the variables of the model.

\subsection{Unit Root Result}

In Table 5, while the PP test shows LnFDI, LnLBF, LnGDPpc and LnTROP as level stationary series and FPI as first difference stationary series at 5 per cent, the ADF test revealed LnFDI, LnLBF and LnTROP as integrated of order zero, and LnGDP and FPI as integrated of order one at 5 per cent.

integrated of order one at 5 per cent.

Table 5: Summary Result of the Unit Root Tests

\begin{tabular}{|l|c|c|c|c|}
\hline Series & \multicolumn{2}{|c|}{ ADF Unit Root Test } & \multicolumn{2}{c|}{ PP Unit Root Test } \\
\hline Level & t - statistic & Remark & t - statistic & Remark \\
\hline LnGDP & -2.352038 & Non-stationary & $-3.961553^{*}$ & Stationary \\
\hline FDI & $-3.493726^{*}$ & Stationary & $-3.493726^{*}$ & Stationary \\
\hline LnLBF & $-4.014271^{*}$ & Stationary & $-12.67531^{*}$ & Stationary \\
\hline FPI & 0.255488 & Non-stationary & -2.245750 & Non-stationary \\
\hline LnTROP & $-3.661780^{*}$ & Stationary & $-10.36885^{*}$ & Stationary \\
\hline $1^{\text {st }}$ diff & \multicolumn{5}{|l}{} \\
\hline d(LnGDP) & $-5.212323^{*}$ & Stationary & $-5.211605^{*}$ & Stationary \\
\hline d(FPI) & $-6.527316^{*}$ & Stationary & $-6.215744^{*}$ & Stationary \\
\hline
\end{tabular}

Note: $*$ and $* *$ represent stationary (intercept) at 5 per cent and trend stationary at 5 per cent Source: Author's computation via Eview

\subsection{Co-integration: ARDL Bound Test}

To verify the existence of the long run relationship in the model, the F-Statistic (Wald Test) is computed and compared with the bound critical values suggested by Narayan (2004). The paper summarizes the findings on the co-integration in Table 4 below. 
Table 6: Summary of ARDL Bound Co-integration Test

\begin{tabular}{|l|c|c|}
\hline \multicolumn{3}{|c|}{ Narayan (2004) Critical Values [restricted intercept and trend] } \\
\hline & Lower Limit & Upper Limit \\
\hline $10 \%$ & 2.716 & 3.888 \\
\hline $5 \%$ & 3.310 & 4.636 \\
\hline $1 \%$ & 4.760 & 6.438 \\
\hline $\mathrm{K}=4$ & \multicolumn{2}{|c}{} \\
\hline
\end{tabular}

Source: Extracted from Narayan (2004)

\section{Computed F-statistic}

$\mathrm{F}_{\text {LnFDI }}()=.8.801 ; \operatorname{FFPI}()=.2.157 ; \operatorname{FLnGDP}()=.8.830 ; \operatorname{FLnLBF}()=.3.172 ; \mathrm{F}_{\operatorname{LnTROP}}()=$.5.314 .

From the result highlighted above, since we find a case where the F-Statistic is greater than the upper bound critical values at 5 per cent, the study found evidence of at least a co-integrating equation in the model. Subsequently, it implies that there is a long-run relationship among the variable of the model. Therefore, the effect of foreign investment inflows on economic growth can be partitioned into the long-run and short-run period horizon.

\section{Long-run Impact of Foreign Investment Inflows on Growth}

From the results tabulated in Table 7, foreign direct investment (FDI) has a positive impact on economic growth. Its estimated coefficient which is 0.036 implies that if the effect of other variables and the constant term on growth in the model is assumed to be zero, on average, increase in FDI inflow by 10 per cent will push up the economic growth rate by about 0.36 per cent in the long-run.

Consequently, the more Nigeria attracts foreign direct investment, the greater would be the level of economic growth in the long-run. At 5 per cent level of significance, the hypothesis conducted revealed that this relationship is true. That is, we find empirical evidence that FDI growth positively contributes to the economic growth in the long-run. This finding is in line with the study of Ibrahim and Akinbobola (2017) conducted between 1986 and 2013 that finds FDI inflows exhibiting a significant long-run positive impact on real GDP.

On the other hand, Foreign Portfolio Investment (FPI) surprisingly has a negative and statistically significant effect on economic growth in the long-run. The coefficient of FPI estimated is -1.11E11; although it is negative and statistically significant, FPI has no operational effect on economic growth in the long run. This is in accordance with the assertion of Ahmad, Cova and Harrison (2014) who argued that although both FPI and FDI are the two basic possible form of foreign investment choice, FPI is highly volatile and may impact on the economic growth negatively; hence, many economies prefer FDI to FPI.

Additionally, the coefficient obtained for the extent to which the Nigerian economy is opened to foreign trade - trade openness, is positive and statistically significant. The magnitude of the impact of trade openness is about 0.479; consequently, a 10 per cent increase in trade openness, ceteris paribus, could lead to about 4.8 per cent level of economic expansion in the long-run. One economic implication of this relation is that Nigeria can achieve a considerable level of economic growth rate in the long run by increasing the level of openness of the economy to foreign trade. 
Finally, the quantity of labour available in the country positively contributes to the growth of economic performance in the long run. The coefficient of labour is highly elastic (about 2.71 per cent) and statistically significant.

Table 7: Summary of the Long run Estimates (ARDL $(1,0,1,0,0)$ )

\begin{tabular}{|l|c|c|c|c|}
\hline Variables & Coefficients & S.E & t-statistic & Prob. \\
\hline LnTROP & $0.479208^{*}$ & 0.052287 & 9.164978 & 0.0000 \\
\hline FPI & $-1.11 \mathrm{E}-11^{*}$ & $4.71 \mathrm{E}-12$ & -2.432799 & 0.0232 \\
\hline LnLBF & $2.707256^{*}$ & 1.254831 & 2.157467 & 0.0417 \\
\hline FDI & $0.036193^{*}$ & 0.012141 & 2.981031 & 0.0067 \\
\hline C & -36.654280 & 21.331021 & -1.718356 & 0.0992 \\
\hline @TREND & $0.068105^{* *}$ & 0.036578 & 1.861942 & 0.0754 \\
\hline
\end{tabular}

Table 8: Summary of the Short run Estimates (ARDL $(1,0,1,0,0)$ )

\begin{tabular}{|l|c|c|}
\hline Variables & Coefficients & S.E \\
\hline D(FDI) & 0.005540 & 0.007778 \\
\hline D(LnTROP) & $0.370906^{*}$ & 0.058922 \\
\hline D(FPI) & $-1.00 \mathrm{E}-11^{*}$ & $1.94 \mathrm{E}-12$ \\
\hline D(LnLBF) & $2.095409^{*}$ & 0.891895 \\
\hline D (@ TREND ()) & $0.052713^{* *}$ & 0.034652 \\
\hline ECM (-1) & $-0.773997^{*}$ & 0.146296 \\
\hline Diagnostic Tests & F-statistic & Obs*R-squared \\
\hline Tests & $0.888972(0.5308)$ & $6.601246(0.4715)$ \\
\hline Breusch-Pagan-Godfrey & B & \\
\hline B-G Correlation LM Test & $0.504727(0.6108)$ & $1.421802(0.4912)$ \\
\hline Ramsey RESET Test (lag 3) $3.449623(0.0361)$ \\
\hline
\end{tabular}

NB: 1) * and ** imply significant at 5 percent and 10 per cent. 2) Values in the parenthesis are the P-values Source: Author's computation

\section{The Short-run Impact of Foreign Investment Inflows on Growth}

Table 8 details the short-run impact of each of the variables of the model on economic growth. The short run coefficient of FDI is 0.006; it is positive but not statistically significant at 5 per cent. Consequently, there is no empirical support that FDI has a positive effect on the economic growth in the short-run. A key reason may be the possibility of substituting FDI with the hosting economy's domestic investment rather than complementing it. Alternatively, acquisition of existing assets of the host economy rather than creating new ones and the rate of capital repatriation may explain better why FDI has no statistically significant impact on economic growth in the short run.

In terms of FPI, it has an estimated short-run coefficient of $-1.00 \mathrm{E}-11$; like in the long run, the size of its coefficient suggests neutral effect on growth if FPI increases or decrease by 100 percent in the short run. The negative sign associated with its coefficient may be an indication of the negative impact of the volatility nature of FPI on economic growth. This coefficient is found to be significant at 5 per cent. Additionally, trade openness has a short-run estimated coefficient of 0.371; the obtained coefficient of trade openness as expected is positive, more elastic than FDI and statistically significant. 
This implies that in the short-run, the magnitude of the impact of trade openness on economic growth is about 0.4 . If we put this differently, it means that the level of sensitivity or elasticity of economic growth to trade openness is up to 0.4 per cent per percentage rise in trade openness. In this regard, trade openness exerts a significant positive impact on the Nigerian economic growth rate in the short run. The economic implication here is that Nigeria should expect more benefit of high economic growth rate from opening up the economy to foreign trade in the long-run than the short-run.

Findings further suggest that labour positively contributes to the economic growth rate more than any other variable in the model. The coefficient obtained for labour is positive, elastic and statistically significant. Subsequently, changes in the growth pattern of the Nigerian economy may be associated with changes in the quantity of labour force in the economy. Finally, the speed of adjustment of the model is -0.773997 per cent. In this case, about 77 per cent of the short run disequilibrium corrected annually.

\section{Conclusion}

In the light of empirical evidence emanating from this study, although the present paper affirms that the foreign investment inflows could momentarily drive up the rate of performance of the Nigerian economy, this does not automatically imply that all the components of the foreign investment inflows bring about a rising rate of growth of the economy. In other words, only foreign direct investment component is identified as a key and noticeable factor upon which the impact of the foreign investment inflows could positively be exerted on the economy. Increase in foreign portfolio investment would only make the Nigerian economy unstable and more susceptible to adverse investment shock. The trade openness and the quantity of labour force could also boost economic performance.

\section{Recommendations}

Nigeria should give much attention to the attraction of FDI component of foreign investment. This will in no small way helps to accelerate Nigeria economic growth in the long run. Also, the Nigeria economy should be more open to foreign trade. Increase in trade openness will promote capital importation or "inward" technological transfer and subsequently a speedy economic growth.

Increasing efforts by the Nigeria government to attract more FPI into the economy may not yield a noticeably fast-paced positive effect on the economy because of its negative and negligible impact on economic growth. This is applicable both in the short run and the long run planning horizons. Emphasis should be on FDI attraction and expansion of the degree of trade flows and increase in the labour supply.

\section{References}

[1] Ahmad, Y.S., Cova, P. and Harrison, R. Foreign Direct Investment versus Portfolio Investment: A Global Games approach, Working Paper 05-03, 2014 November.

[2] Albulescu, C. T. Do Foreign Direct and Portfolio Investments Affect Long-Term Economic Growth in Central and Eastern Europe? Procedia Economics and Finance Vol. 23, 2015, 507-12. Retrieved from www.sciencedirect.com 
[3] Baghebo, M. and Apere, T. Foreign Portfolio Investment and Economic Growth in Nigeria, International Journal of Business and Social Science. Vol.5, No.11, 2014, 108 - 115. Retrieved from www.ijbssnet.com

[4] Bhagwati, J.N., Free Trade: Old and New Challenges. Economic Journal, Vol.104, 1994, 231-246.

[5] Blanchard, O. and Johnson, D.R. Macroeconomics, 6th Ed. New York. Pearson Publishing, 2013.

[6] Brecher R. A Second-best Policy for International Trade and Investment, Journal of International Economics, Vol.14, No.3-4, 1983, 313-320.

[7] Brecher, R.A. and Alejandro, C.F.D. Tariffs, Foreign Capital and Immiserizing Growth, Journal of International Economics, Vol.7, No.3, 1977,317-322.

[8] Brecher, R.A. and Findlay, R. Tariff, Foreign Capital and National Welfare with Sector Specific Factors, Journal of International Economics, Vol.14, 1983, 277-288.

[9] Ibrahim T. R., Akinbobola, T.O. Foreign Portfolio Investment and Economic Growth in Nigeria Democratic Settings, Journal of Economics and Sustainable Development. Vol.8, No.5, 2017,3352. Retrieved from www.iiste.org

[10] Jhingan, M.L., Macroeconomics Theory, 11th Reversed and Enlarged Ed. Delhi, Vrinda Publishing, 2013.

[11] Kania-Morales, J., and Mroz, R. Relationship between Foreign Direct Investment Stock and Foreign Portfolio Investment Stock. Do they really matter for GDP in Poland, Germany, and Great Britain? Ekonomia Journal, Vol.38, 2014,97-127.

[12] Mankiw, N.G., Romer, D. and Weil, D.N. A Contribution to the Empirics of Economic Growth. Quarterly Journal of Economics. Vol.107, 1994, 407- 437. Retrieved from www.transcampus.org/journal

[13] Moosa, I. Foreign Direct Investment: Theory, Evidence and Practice. New York, Palgrave. 2002.

[14] Narayan, P. K. Reformulating Critical Values for the Bounds F-Statistics Approach to Cointegration: An Application to the Tourism Demand Model for Fiji. Department of Economics, Monash University Discussion Papers. 2004 Retrieved from https://www.researchgate.net/publication/268048533

[15] NIPC, Invest in Nigeria, 2018, Available at https://www.nipc.gov.ng/investment-incentives/

[16] Obadan, M.I. Foreign Investment Flows to the Nigerian Economy, Draft. 2004, Retrieved from www.academix.ng/documents/papers/1449052162_7128.pdf

[17] Odubola, I.O. and Desalu, A.O. Analysis of the Impact of Foreign Direct Investment and Domestic Investment on Economic Growth in Nigeria, Equatorial Journal of Social Sciences and Human Behaviour, Vol.2, No.4, 2017, 121-134.

[18] Okafor, I. G., Ugochukwu, U.S. and Chijindu, E.H. Foreign Capital Inflows and Nigerian Economic Growth Nexus: A Toda Yamamoto Approach. European Journal of Accounting, Auditing and Finance Research, Vol.4, No.3, 2016, 16-26. Retrieved from www.eajournals.org

[19] Onosode, G. O. The Capital Market and Nigeria's Economic Development, 1998, In Obadan, M.I., Foreign Investment Flows to the Nigerian Economy, Draft. Retrieved from www.academix.ng/documents/papers/1449052162_7128.pdf

[20] Onyeisi, O.S., Odo, I.S. and Anoke C.I. Foreign Portfolio Investment and Stock Market Growth in Nigeria. Developing Country Studies. Vol.6, No.11, 2016, 24-76. Retrieved from www.iiste.org

[21] Ozurumba, B.A. The Impact of Stock Market Returns on Foreign Portfolio Investment in Nigeria, IOSR Journal of Business and Management, Vol.2, No.4, 2012, 10-19. Retrieved from www.iosrjournals.org

[22] Pesaran, M.H., Shin, Y. and Smith, R.J. Bounds Testing Approaches to the Analysis of Level Relationships, Journal of Applied Econometric, Vol.16, 2001, 289-326.

[23] Razin, A. FDI Contribution to Capital Flows and Investment in Capacity, NBER Working Paper No. W9204, 2002, September.

[24] Ricardo, D., On the Principles of Political Economy and Taxation, 1951, In Vol. I of the Works and Correspondence of David Ricardo, edited by Sraffa, P and Dobb, M. H., Cambridge: Cambridge University Press, 
[25] Romer, D., Advanced Macroeconomics, 4th Ed. New York, McGraw-Hill, Inc., 2012

[26] Snowdon, B., and Vane. H.R., Modern Macroeconomics: Its Origins, Development and Current State, USA, Edward Elgar Cheltenham Publishing, 2005.

[27] Tang D., Has the Foreign Direct Investment Boosted Economic Growth in the European Union Countries? Journal of International and Global Economic Studies, Vol.8, No.1, 2015,21-50

[28] Todaro, M.P., Economic Development. 5th Ed. New York and London. Longman. 1994

[29] Todaro, M.P. and Smith, C.S., Economic Development, 11th edition. New York. Addison-Wesley. 2012

[30] Tumala, M.M., Ajibola, O. I., Omotosho, B.S. and Baruwa O.A., Survey of Foreign Assets and Liabilities in Nigeria 2011 Report, CBN Journal of Applied Statistics, Vol.3, No.2, 2013, 143-165

[31] WDI. World Bank Development Indicator, 2018. Retrieved from www.data.worldbank.org

*Corresponding author.

E-mail address: adediyan@yahoo.com/emmanuelekomoezor@gmail.com 